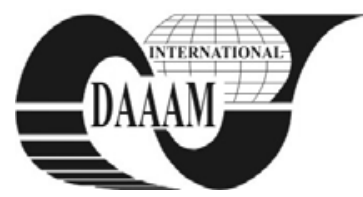

Annals of DAAAM for 2011 \& Proceedings of the 22nd International DAAAM Symposium, Volume 22, No. 1, ISSN $1726-9679$ ISBN 978-3-901509-83-4, Editor B. Katalinic, Published by DAAAM International, Vienna, Austria, EU, 2011 Make Harmony between Technology and Nature, and Your Mind will Fly Free as a Bird Annals \& Proceedings of DAAAM International 2011

\title{
VALUE OPTIMIZATION AND RISKS ELIMINATION OF PRODUCT
}

\author{
BROUM, T[omas]; DVORAK, J[osef] \& KLEINOVA, J[ana]
}

\begin{abstract}
The requirements of customers and society significantly increase the ever higher and higher requirements on quality, cost and delivery time of technical products. There are many products on the market today which achieve a high level of technical perfection although customers do not need it. This high technical excellence is often connected to higher costs. This is why it is necessary to place products of appropriate usage value on the market. The value analysis methodology can help for this purpose. A product has to meet some standards and criteria. Whether or not a product meets the criteria can be evaluated by risk analysis. The aim of this paper is to describe a methodology for obtaining an optimized product without risks. The new methodology connects previously mentioned methodologies.
\end{abstract}

Key words: risks, value analysis, value, product, risk analysis

\section{INTRODUCTION}

Because of higher and higher demands on designed technical products, the requirements on quality and shortening of their Life and Innovation Cycle increase substantially. These inputs influence not only the functions or shapes of technical products but they also have a distinct impact on their usable quality, material usage, costs and delivery times. At present all these aspects force designers to design proposals of technically perfect products. The ideal state is to design a product with as high quality as possible with the shortest manufacturing time together with as low costs as possible. There are many products now on the market which achieve such high technical perfection even though customers do not request it. This is why it is necessary to deliver products to the market with adequate usability value. Of course these products also have to meet the requirements of requested criteria and standards. In this paper a new concept of a methodology for designing such technical products is presented.

When a designer designs a technical product he brings to the future product not only shapes and functions but also designs and predicts its other properties including life cycle costs and delivery times. Designing is the key phase of a product's life cycle. It is essential to support this phase by using new and innovated knowledge, methodologies, tools etc. Not only for the designing phase itself but also for subsequent phases of the life cycle of the technical product. Continuous and quick technical progress brings also risks and designers have to face to them. Projects for new technical products are endangered by risks. Thus timely indication and identification of those risks are irreplaceable parts for designers and management. Mistakes cause costs. When a mistake is found during designing it causes some costs. In subsequent phases the cost caused by a mistake is multiplied.

That is why the requirements of design management are constantly growing. There are many approaches, methods or tools which support processes connected to designing. The aim of these methods is to design technical products which will find the right place on the market and become fully competitive.

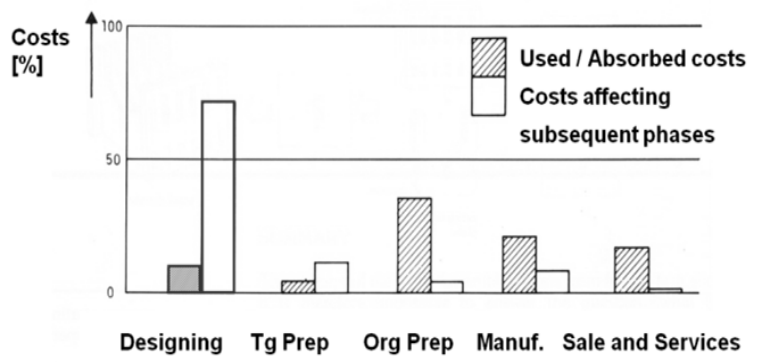

Fig. 1. Ratio of total costs of product's life cycle phases (Ehrlenspiel 2007)

As can be seen in Fig. 1, the design phase is the crucial phase of the life cycle of a product. This phase absorbs quite low costs (by percentage) but in comparison with other phases influences about seventy percent of subsequent costs. This is why we are interested in this phase. It is necessary to design a product not only effectively but also efficiently. As was mentioned there are many tools or approaches for designing competitive products. The new concept of a manager's tool is described in this paper. This concept consists of value analyses and subsequent risk analyses.

\section{VALUE ANALYSIS}

Value analysis is a methodology that concentrates on optimization of product value. Value analysis is a tool for initiating of innovations by functional-cost analysis (Broum et al., 2010). Value analysis can be defined as follows (ČSN, 1997): Value analysis is an organized and creative approach that uses processes of functional and economical design with the purpose of increasing the value of the solved object. Then the term 'value' must be defined. Value is understood as the ratio between functions and costs of a product. 'Function' is (Dostal et al., 2009): defining or determining activities, operations or abilities of the solved object, which ensure a certain need by the aspect of the needs.

The value analysis approach is connected to the answering of the following questions (Miles, 1971):

- What is the item or service?

- What does it cost?

- What does it do?

- What else would do the job?

- What would that alternative cost?

Work on value analysis is controlled and organized by a job plan of the value analysis. Job plans are different according to the different approaches of their authors. One of the job plans is mentioned below (Dostal et al., 2009), (ČSN, 2000):

0 - Preliminary phase

1 - Project definition

2 - Planning 
3 - Capture of data about studies

4 - Functional analysis, Cost analysis

5 - Making of subject for new solutions

6 - Evaluation of ideas about solutions

7 - Development of global proposals

8 - Presentation of proposal

9 - Implementation

\section{RISK ANALYSIS}

Cost balancing by using value analyses is not enough to design a highly competitive product. The product has to meet many criteria to be released on the market. These criteria are stated by corresponding standards. In the EU (European Union) technical products which are placed on the market have to gain the CE certificate (a trademark which expresses compliance with EU standards). A CE trademark is obligatory and has to be attached before any technical product which is under those duties is placed on the market or even in operation. That is why it is necessary to put the product under risk analyses. The aim of risk analyses is to compare the parameters of a real/designed product with boundary parameters. Those parameters which do not meet the criteria, in other words parameters which transcend boundary parameters, must be rearranged. We consider all the parameters to be properties which we can measure and express by property indicators which are characterized by values of property indicators.

GTS

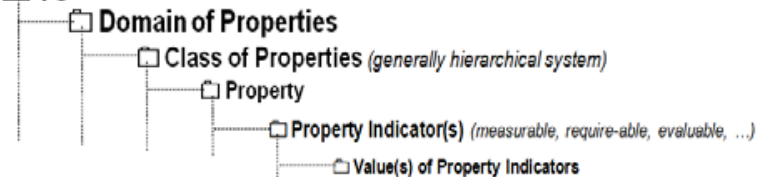

Fig. 2. Hierarchical taxonomy system for specification of any Technical Product's (TS) Property (Hosnedl et al., 2010)

\begin{tabular}{|c|c|c|c|c|}
\hline Property P & $\begin{array}{c}\text { Property } \\
\text { Indicator PI }\end{array}$ & $\begin{array}{c}\text { Value of PI } \\
\text { VPI }\end{array}$ & $\begin{array}{c}\text { Limit of } \\
\text { Value of } \\
\text { PI LVPI }\end{array}$ & $\begin{array}{c}\text { Risk } \\
\text { Indicator } \\
\text { RI }\end{array}$ \\
\hline Safety & $\begin{array}{c}\text { Braking } \\
\text { distance }\end{array}$ & $10 \mathrm{~ms}^{-2}$ & $10 \mathrm{~ms}^{-2}$ & VPI=LVPI \\
\hline Safety & $\begin{array}{c}\text { Number of } \\
\text { airbags }\end{array}$ & 4 & 5 & VP<LVPI \\
\hline Adjustability & Vertical lean & $40^{\circ}$ & $35^{\circ}$ & VPI $>$ LVPI \\
\hline$\ldots$ & $\ldots$ & $\ldots$ & $\ldots$ & $\ldots$ \\
\hline
\end{tabular}

Tab. 1. Depiction of risk indication when VP<LVPI

\section{NEW APPROACH}

The new approach that enables analysis and elimination of risk of an optimized product by value analysis is obtained by connecting value analysis and risk analysis. This connection is shown in Figure 3. According to Figure 3 optimization of a product by value analysis methodology is done first. The optimized product may also have some risks that can be higher than the limits. This is the reason for risk analysis. If the discovered risks exceed the limits of risks, then those risks must be eliminated. Risk elimination can decrease the product value, so the value analysis must be done again. Then the proposal is checked again by risk analysis. This cycle runs until all risks are below the limits. Then we obtain an optimized product without risks and such product should be fully competitive on market.

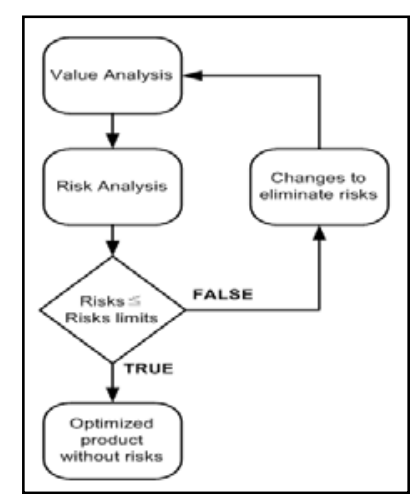

Fig. 3. Optimized cycle of product design

\section{CONCLUSION}

The paper looks at known methodologies - value analysis and risk analysis. The paper concentrates on the problematics of product development; first the product must meet all criteria and standards, so the risks must be below the limits of risks. The product should also have the appropriate value for the customer. This is ensured by value analysis methodology. The combination of these approaches in the cycle described here could lead to increasing the competitiveness of the product. By connecting the approaches a new approach is obtained. The new approach should lead to obtain an optimize product without risks.

\section{ACKNOWLEDGEMENTS}

This paper includes results from Project No. 402/08/H051 Optimization of multidisciplinary designing and modelling of production systems subsidised by the Grant Agency of the Czech Republic.

\section{REFERENCES}

Broum, T.; Kopecky, M. \& Kleinova, J. (2010). Enhancement of Value Analysis using the Theory of Technical Systems. DAAAM Symposium, ISBN 978-3-901509-73-5, ISSN 1726-9679, Vienna, Austria 2010

Hosnedl, S., Dvořák, J., Srp, Z., Kopecký, M. "Design Specification and Evaluation Tool for Design Engineering and its Management". In: Proceedings of the 11th International Design Conference - DESIGN 2010, D. Marjanovic et al.( Eds.), FMENA, Zagreb, 2010, pp. 799 810. ISBN 978-953-7738-07-5

Hosnedl, S. and Vanek, V. Engineering Design Science based Design Research for Education and Practice. In: Special Issue of the Selected Articles of the 1st Conf. on Design Engineering and Science - ICDES2005. Tokio: Japan Society for Design Engineering, 2006, p. 31-36

Ehrlenspiel, K. , Kiewert, A., and Lindemann, U. Cost-Efficient Design. Berlin Heidelberg: Springer-Verlag, 2007. ISBN 10 3-540-34647-3, ISBN 13978 3-540-34647-3

*** (2000) Czech national technical standard, ČSN EN 12973 Hodnotový management, ČNI, Prague, Czech Republic

Dostál, V.; Loubal, J. \& Bartes, F. (2009). Hodnotové inženýrství, KEY Publishing s.r.o., ISBN 978-80-7418-0033, Ostrava, Czech Republic

Šimon, M. \& Troblová, P. (2007). Effective design aspects of production system, In: Annals of DAAAM for 2007, str.691692, ISBN 3-901509-58-5, Zadar, Croatia

*** (1997) Czech national technical standard, ČSN EN 1325-1, ČNI, Prague, Czech Republic

Miles, L.D.(1971). Hodnotová analýza, ALFA n.p., ISBN 63045-71, Bratislava,Czechoslovakia 